\title{
Improving energy efficiency of apple production by reduced application of pesticides
}

\author{
Aleksandar Sedlar ${ }^{1}$, Ondrej Ponjičan ${ }^{1}$, Ferenc Kiss ${ }^{2}$, Rajko Bugarin ${ }^{1}$, Vladimir Višacki ${ }^{1 *}$, \\ Milivoj Radojčin ${ }^{1}$, Krstan Kešelj $^{1}$ \\ (1. University of Novi Sad, Faculty of Agriculture, Trg Dositeja Obradovića 8, 21000 Novi Sad, Serbia; \\ 2. University of Novi Sad, Faculty of Technology, Blv. Cara Lazara 1, 21000 Novi Sad, Serbia)
}

\begin{abstract}
A large number of apple orchards are treated over 20 times during the vegetation period with high application rates (over $1000 \mathrm{~L} / \mathrm{hm}^{2}$ ) or medium application rates $\left(500-1000 \mathrm{~L} / \mathrm{hm}^{2}\right.$ ) of pesticides which require significant energy input. Experimental research was carried out in the Serbian region of Vojvodina with the aim to show the possibilities to reduce energy usage in apple production by reducing pesticide application rates $\left(200-500 \mathrm{~L} / \mathrm{hm}^{2}\right)$ and smaller controlled number of treatments with pesticides while maintaining the biological efficiency of apple chemical protection. Research results showed that the cumulative life cycle energy demand of apple production in Vojvodina, assuming a typical 22 annual treatments and relatively high pesticide application rate $\left(1150 \mathrm{~L} / \mathrm{hm}^{2}\right)$, was $48 \mathrm{GJ} / \mathrm{hm}^{2}$ and energy output was $94 \mathrm{GJ} / \mathrm{hm}^{2}$. Reduced number of treatments and lower pesticide application rates have a favorable impact on energy inputs associated with diesel fuel, machinery, chemicals, water and electricity consumption and usage, whereas other energy inputs remain unchanged. The energy input for 12 treatments with pesticide application rates of $381 \mathrm{~L} / \mathrm{hm}^{2}$ was $36 \mathrm{GJ} / \mathrm{hm}^{2}$, which is a $25 \%$ reduction in comparison to 22 treatments with a pesticide application rate of $1150 \mathrm{~L} / \mathrm{hm}^{2}$. Reduced number of treatments and pesticide application rate increased the energy use efficiency from 1.96 to 2.61 , energy productivity from $0.82 \mathrm{~kg} / \mathrm{MJ}$ to $1.09 \mathrm{~kg} / \mathrm{MJ}$, and net energy from $46 \mathrm{GJ} / \mathrm{hm}^{2}$ to $58 \mathrm{GJ} / \mathrm{hm}^{2}$. Results also suggest that applying the correct IPM approach can easily lead to a strong reduction in the number of treatments and a major energy saving.
\end{abstract}

Keywords: apple production, energy flow, pesticide application rates, total energy input, energy balancing DOI: $10.25165 /$ j.ijabe.20201304.5743

Citation: Sedlar A, Ponjičan O, Kiss F, Bugarin R, Višacki V, Radojčin M, et al. Improving energy efficiency of apple production by reduced application of pesticides. Int J Agric \& Biol Eng, 2020; 13(4): 93-102.

\section{Introduction}

Apple (Malus silvestris) is one of the main fruit crops in Europe and it is the $4^{\text {th }}$ ranked fruit in the world after banana, citrus, and melons. Apple fruit is very important from the economic aspect as well because it belongs to the category of fruits which require highly complex production technology, considerable labor input and financial resources, but it is highly accumulative and cost effective. In comparison to wheat production, apple growing provides 10-20 times as much production value per hectare ${ }^{[1]}$.

Apple is the second most commonly grown fruit in Serbia (15\% out of all fruit crops), preceded by the plum. Apple is the most frequently grown fruit in Vojvodina, which is in the northern

\section{Received data: 2020-02-19 Accepted data: 2020-05-09}

Biographies: Aleksandar Sedlar, PhD, Associate Professor, research interests: agricultural Engineering, Email: alek@polj.uns.ac.rs; Ondrej Ponjičan, PhD, Associate Professor, research interests: agricultural engineering, Email: ondrej.ponjican@polj.uns.ac.rs; Ferenc Kiss, PhD, Research Fellow, research interests: agricultural economics, life cycle assessment (LCA), Email: fkiss@tf.uns.ac.rs; Rajko Bugarin, PhD, Associate Professor, research interests: agricultural engineering, Email: brajko@polj.uns.ac.rs; Milivoj Radojčin, PhD, Assistant Professor, research interests: agricultural engineering, Email: milivoj.radojcin@polj.uns.ac.rs; Krstan Kešelj, MSc, Research Assistant, research interests: agricultural engineering, Email: krstan.keselj@polj.uns.ac.rs. *Corresponding author: Vladimir Višacki, MSc, Assistant, research interests: agricultural engineering. University of Novi Sad, Faculty of Agriculture, Trg Dositeja Obradovića 8, 21000 Novi Sad, Serbia. Tel: +381-631591438, Email: vladimir.visacki@polj.edu.rs. part of the Republic of Serbia and the most important agricultural region. More than one third (ca. $77000 \mathrm{t}$ ) of the total annual production of apples in Serbia (ca. $200000 \mathrm{t}$ ) is grown in Vojvodina $^{[1]}$. According to statistical data from 2007, the biggest number of fruitful trees could be found in the South-Banat region of Vojvodina (1.2 million) and North-Bačka region (1 million) where $20 \mathrm{~kg}$ of fruit per tree was an average yield. After 2007, the size of the apple orchards increased both in Vojvodina and Serbia.

The total land used for apple orchards in Serbia is $23737 \mathrm{hm}^{2}$, out of which $6347 \mathrm{hm}^{2}$ is located in Vojvodina ${ }^{[2]}$. Apple production technology with inter-row distance from $3.6 \mathrm{~m}$ to $4 \mathrm{~m}$ and $1.2 \mathrm{~m}$ to $1.6 \mathrm{~m}$ of the distance between trees in the rows is applied on over $80 \%$ of the planting area. These orchards do not have installed anti-hail nets and they are usually not irrigated. Only $13.4 \%$ of land which is used for fruit production is irrigated ${ }^{[2]}$. Those are mainly soft fruits and modern high density apple orchards which have become more and more common over the last 5 to 10 years. Nowadays, there are less than $20 \%$ of high density apple orchards (3.2 $\mathrm{m} \times 0.6-0.8 \mathrm{~m})$ which have an irrigation system and anti-hail nets.

One problem particularly related to apple growing is the number of chemical treatments and application rates. One of the previous research showed that more than $60 \%$ of orchards were treated more than 20 times ( 22 treatments on average) with high (over $1000 \mathrm{~L} / \mathrm{hm}^{2}$ ) or medium $\left(500-1000 \mathrm{~L} / \mathrm{hm}^{2}\right.$ ) pesticide application rates ${ }^{[3]}$. This number of more than 22 treatments per year is useless and very dangerous from an environmental and 
healthy point of view.

Energy flow was also tested in the integral apple production in Greece $^{[4]}$. Chemical protection made $40 \%$ of total energy input. The results of their research showed that energy saving can be achieved by reducing the fertilization (especially $\mathrm{N}$ ) and application of chemical agents, as well as by implementing adequate technology without significant reduction in yield quality and quantity. The energy input for chemical protection depends primarily on the climate where apples are grown. The energy input for chemical protection in Turkey is $18.1 \%{ }^{[5]}$, and in Iran, it is only $12.3 \%$ of total energy input ${ }^{[6]}$.

High pesticide application rates and a number of treatments imply high energy input, increased production costs and a threat from the aspect of environmental protection. During the application of chemical agents, the losses of fluid that occur due to air and ground drift pose danger because of soil and air pollution. The reduction of potential risks of polluting natural resources is ensured with a reduced number of treatments and lower pesticide application rates.

The objective of this research was to determine the main energy inputs for the production technology applied in the Vojvodina region, the Republic of Serbia. This research also aimed at indicating the possibilities of reduced energy inputs with respect to chemical protection by using lower pesticide application rates $\left(200-500 \mathrm{~L} / \mathrm{hm}^{2}\right)$ and smaller controlled number of treatments but maintaining the biological efficiency of apple chemical protection. The analysis of apple production technology was conducted in 2009 and 2010 with particular attention paid to chemical protection.

\section{Materials and methods}

\subsection{Orchard characteristics}

The research was conducted at an orchard managed by the Department of fruit growing, viticulture, horticulture and landscape architecture $\left(45^{\circ} 20^{\prime} 18.9^{\prime \prime} \mathrm{N} ; 1^{\circ} 50^{\prime} 30^{\prime \prime} \mathrm{E}\right)$ of the Faculty of Agriculture in Novi Sad, Serbia. The Idared apple orchard was established in 1997 on M9 rootstock, with a slender spindle type of training system. It was established on degraded chernozem soil with 3\% organic matter content. Macro relief is flat, and microrelief is mostly flat with slight depression between the rows, about $10 \mathrm{~cm}$ deep. The planting distance is $4 \times 1.2 \mathrm{~m}$ and the orchard is not equipped with anti-hail nets or irrigation systems. Given these characteristics, it could be considered as a typical apple orchard in Vojvodina, Serbia.

\subsection{Inputs associated with apple production}

During the research, all relevant inputs of material, energy and human labor were systematically monitored and measured. The productivity $\left(\mathrm{hm}^{2} / \mathrm{h}\right)$ and fuel consumption $\left(\mathrm{L} / \mathrm{hm}^{2}\right)$ of specific agrotechnical operations were determined based on on-site measurements. Fuel consumption was measured by the volume method using the Pierburg 2911 flow meter (accuracy level $\pm 0.5 \%$ ), Figure 1.

The working speed was measured with a device installed on the tractor rear wheel. The instrument was built-in Optocapler
GP1A70R (Sharp) sensors (produced by TRCpro, Serbia). Eight-channel acquisition unit Spider8 (HBM, Germany) connected to $\mathrm{PC}$ was used for the data collection and storage ${ }^{[7]}$.

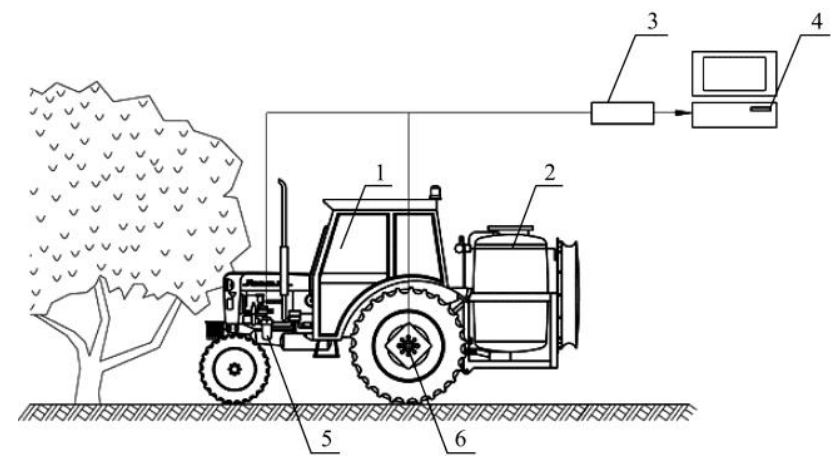

1. Tested tractor 2. Air assisted sprayer 3. Acquisition (Spider 8) 4. PC 5. Fuel flow meter Pierburg 2911 6. Velocity sensor (Optocapler GP1A70R Sharp)

Figure 1 Scheme of measuring equipment

\subsection{Insect/decease control}

The apple orchard was treated 12 times out of which two treatments included only fungicides, whereas ten treatments were a combination of fungicides and insecticides, Table S1. In contrast to the more than 20 treatments with application high pesticide application rate over $1000 \mathrm{~L} / \mathrm{hm}^{2}$, typically applied preventively in Vojvodina when constant monitoring of disease and pest development is not possible ${ }^{[8]}$. The orchard was divided into three parts: the control part, and parts treated with medium and low pesticide application rates which were $759 \mathrm{~L} / \mathrm{hm}^{2}$ and $381 \mathrm{~L} / \mathrm{hm}^{2}$, respectively. Biological efficiency of reduced pesticide application rate and the number of treatments was studied during the two years of the experiment.

Applications of insecticides and fungicides were performed with a carried air assisted sprayer Agromehanika 440 (AGP 440) mounted on a tractor Rakovica 65 with a nominal power of $47 \mathrm{~kW}$. The sprayer had a $400 \mathrm{~L}$ tank. The fan was axial with adjustment of fan speed (12 to $32 \mathrm{~m} / \mathrm{s}$ ), max $1400 \mathrm{r} / \mathrm{min}$ fan rotating speed and airflow capacity (16 000 to $48000 \mathrm{~m}^{3} / \mathrm{h}$ ). The air assisted sprayer was equipped with 12 Lechler TR 80-02 nozzles for low rates and 12 Lechler TR 80-04 nozzles for medium and high pesticide application rates which were under pressure of 8 bar for low and medium rates, and 15 bar for high pesticide application rate. Duration and fuel consumption of specific operations associated with chemical protection of apple orchard by air assisted sprayer is given in Table 1. The longest amount of time was spent on the forming spraying aggregate and traveling from the commercial yard to the orchard, and its return (4000 s). The orchard had a water source so the tank was filled and work fluid was prepared there. The average distance from the point of tank filling to the point of treatment in the orchard was about $1 \mathrm{~km}$. The average working speed of the aggregate during treatment was $5.70 \mathrm{~km} / \mathrm{h}$. The length of rows in the tested orchard is $200 \mathrm{~m}$ long. Treatment of one row lasted for $127 \mathrm{~s}$ with fuel consumption of $4.20 \mathrm{~L} / \mathrm{h}$. The turning of the aggregate at the end of the rows required, on average, additional $30 \mathrm{~s}$ (Table 1).

Table 1 Measured value of working time structure and fuel consumption during the treatment of apple orchard (2009 and 2010)

\begin{tabular}{lcccc}
\hline \multicolumn{1}{c}{ Working time structure } & Time parts $\left(x_{i . t}\right) / \mathrm{s}$ & Working speed $/ \mathrm{km} \cdot \mathrm{h}^{-1}$ & Hourly fuel consumption/L· $\mathrm{h}^{-1}$ & Fuel consumption $\left(x_{i . f}\right) / \mathrm{L}$ \\
\hline Preparation and finishing activities $\left(x_{1}\right)$ & 4000 & - & 3.04 & 3.378 \\
Preparation of fluid for the treatment $\left(x_{2}\right)$ & 600 & - & 2.73 & 0.456 \\
Travelling to the orchard $\left(x_{3}\right)$ & 630 & 5.81 & 3.19 & 0.559 \\
Treatment (one row) $\left(x_{4}\right)$ & 127 & 5.70 & 4.20 & 0.148 \\
Turning at the end of the row $\left(x_{5}\right)$ & 30 & 0.35 & 2.73 & 0.023 \\
Driving back $\left(x_{6}\right)$ & 600 & 5.79 & 3.04 & 0.532 \\
\hline
\end{tabular}


Based on the measured values presented in Table 1 several parameters such as labor productivity and annual fuel consumption can be derived which serve as the basis for energy balance. Treatment of one row covers an area of $800 \mathrm{~m}^{2}$, therefore, at pesticide application rates of $381 \mathrm{~L} / \mathrm{hm}^{2}, 759 \mathrm{~L} / \mathrm{hm}^{2}$ and $1150 \mathrm{~L} / \mathrm{hm}^{2}$ the consumption per one row is $30.48 \mathrm{~L}, 60.72 \mathrm{~L}$ and
$90.00 \mathrm{~L}$, respectively (Table 2 ). The time required to empty one tank $(c)$ was determined based on the number of rows treated with one tank $(b$, Table 2$)$ and the estimated working time $\left(x_{i . t}\right)$ associated with each of the operation (Table 1) using the following equation:

Time required to empty one tank $(c)=x_{2, t}+x_{3, t}+x_{6, t}+\left(x_{4, t}+x_{5, t}\right) \cdot b$

Table 2 Calculated values of productivity, working hours and fuel consumption for pesticide application rates and number of treatments

\begin{tabular}{|c|c|c|c|c|c|}
\hline \multirow{2}{*}{ Symbol } & \multirow{2}{*}{ Parameter } & \multirow{2}{*}{ Unit } & \multicolumn{3}{|c|}{ Pesticide application rates $/ \mathrm{L} \cdot \mathrm{hm}^{-2}$} \\
\hline & & & 381 & 759 & 1150 \\
\hline$a$ & Application rate per one row & $\mathrm{L} \cdot$ row $^{-1}$ & 30.48 & 60.72 & 90.00 \\
\hline$b$ & Number of rows treated with one tank & - & 12 & 6 & 4 \\
\hline$c$ & Discharging period of one tank, eq. $1, c$ & $\mathrm{~s}$ & 3744 & 2802 & 2488 \\
\hline$d$ & Area treated with one tank, $d=0.08 \mathrm{hm}^{2} \times b$ & $\mathrm{hm}^{2}$ & 0.96 & 0.48 & 0.32 \\
\hline$e$ & Number of cycles (tank discharges) for 8 hours, $e=\left(8 \mathrm{~h} \times 3600 \mathrm{~s}-x_{1, t}\right) / \mathrm{c}$ & - & 6 & 8 & 9 \\
\hline$f$ & Productivity for $8 \mathrm{~h}, f=e \times d$ & $\mathrm{hm}^{2} \cdot 8 \mathrm{~h}^{-1}$ & 5.76 & 3.84 & 2.88 \\
\hline$g$ & Productivity, $g=f / 8$ & $\mathrm{hm}^{2} \cdot \mathrm{h}^{-1}$ & 0.72 & 0.48 & 0.36 \\
\hline$h$ & Working hours per one treatment, $h=1 / g$ & $h \cdot h m^{-2}$ & 1.39 & 2.08 & 2.78 \\
\hline$i$ & Total working hours ( 12 treatments), $i=h \times 12$ & $h \cdot h m^{-2}$ & 16.67 & 25.00 & 33.33 \\
\hline$j$ & Total working hours ( 22 treatments),$j=h \times 22$ & $h \cdot h m^{-2}$ & 30.56 & 45.83 & 61.11 \\
\hline$k$ & Fuel consumption for one tank of a sprayer, eq. $2, k$ & $\mathrm{~L} \cdot \operatorname{tank}^{-1}$ & 3.597 & 2.572 & 2.230 \\
\hline$l$ & Fuel consumption per unit of treated area, $1=\left((e \times k)+x_{1, f}\right) / f$ & $\mathrm{~L} \cdot \mathrm{hm} \mathrm{m}^{-2}$ & 4.333 & 6.238 & 8.143 \\
\hline$m$ & Total annual fuel consumption ( 12 treatments), $m=1 \times 12$ & $\mathrm{~L} \cdot \mathrm{hm}^{-2}$ & 52.00 & 74.86 & 97.71 \\
\hline$n$ & Total annual fuel consumption ( 22 treatments), $n=1 \times 22$ & $\mathrm{~L} \cdot \mathrm{hm} \mathrm{m}^{-2}$ & 95.33 & 137.24 & 179.14 \\
\hline
\end{tabular}

Labor productivity per hour was calculated as a ratio between the treated area and time required for the treatment, and with respect to the pesticide application rate, it was $0.72 \mathrm{hm}^{2} / \mathrm{h}$, $0.48 \mathrm{hm}^{2} / \mathrm{h}$ and $0.36 \mathrm{hm}^{2} / \mathrm{h}$ (Table 2). The total working hours required for different numbers of treatments and pesticide application rates were determined (Table 2) based on the productivity and served as input value in energy balancing. It was assumed that the application of insecticides and fungicides requires only one worker (tractor operator).

The amount of fuel consumed during the period while one sprayer tank is fully discharged $(k)$ was calculated with Equation (2) using the values of fuel consumption $\left(x_{i, f}\right)$ for individual operations during treatment (Table 1) and the number of rows treated with one tank (b) with respect to the pesticide application rate (Table 2). Based on this value the fuel consumption per unit of area and the annual fuel consumption for 12 and 22 treatments could be also determined (Table 2).

Fuel consumption for one tank of a sprayer $(k)=$

$$
x_{2, f}+x_{3, f}+x_{6, f}+\left(x_{4, f}+x_{5, f}\right) \cdot b
$$

The annual fuel consumption required for the application of pesticides varied in a significant range from 52 to $179 \mathrm{~L} / \mathrm{hm}^{2}$ depending on the number of treatments and pesticide application rates (Table 2).

\subsection{Other agrotechnical operations}

Apart from insect/decease control, the production technology involves tillage, weed control, harvesting, pruning, mulching and application of fertilizers. Tillage was performed four times during the year with a surface cultivator at a depth of $13 \mathrm{~cm}$. Weed control was carried out three times a year with a manual sprayer that had a 10 litre tank. The treated parts were only those that were not tilled with a cultivator. The herbicide used was based on glyphosate active ingredient. Mineral fertilizers (NPK 8:16:24) were applied with a spreader that was pulled between rows and the application rate of fertilizer was $400 \mathrm{~kg} / \mathrm{hm}^{2}$. Manual pruning was performed with pruning shears and saws in autumn, and the pruning wood was mulched with INO Brežica mulcher with $1.6 \mathrm{~m}$ working width. Surface cultivator with $2 \mathrm{~m}$ work width was used for soil tillage, incorporation of mineral fertilizer and pruning wood, and for weed removal.

Apples were harvested and selected manually three times and stored in wooden crates. The average yield at various application rates was $39240 \mathrm{~kg} / \mathrm{hm}^{2}$ with a standard error of $2132 \mathrm{~kg} / \mathrm{hm}^{2}$. At $5 \%$ significance threshold, there were no statistically significant differences between yields. The observed minor variations in yields were not the consequence of differences in the application rate and the number of treatments ${ }^{[3]}$. Therefore, to make the different production systems comparable, the average yield of $39240 \mathrm{~kg} / \mathrm{hm}^{2}$ was used throughout the energy balancing. The fruit was transported $1 \mathrm{~km}$ to the commercial yard in a tractor-trailer with a net load of $8 \mathrm{t}$.

\subsection{Summary of inputs associated with apple production}

Average values of input of labor, fuel and chemical agents that were used for technological operations during the two-year-long research are summarized in Table 3.

\subsection{Energy equivalents of input and output flow}

The total energy equivalent is calculated by multiplying the inputs with respective energy equivalents. The energy equivalent of input equals the quantity of primary energy used in the whole life cycle of input. Energy equivalents of various inputs are available from published sources and there are often used in energy balancing of agricultural products ${ }^{[4,5,9]}$. However, there is an enormous variation in energy equivalents reported in the literature. The energy equivalent of a specific input may vary in significant range depending on the chosen spatial and temporal system boundaries, the production technologies and methods used for its estimation $^{[10]}$. Thus, instead of relying on pre-calculated values from previous studies, in this study, the input specific energy equivalents were calculated using the cumulative energy demand (CED) method ${ }^{[23,24]}$. 
Table 3 Inputs per hectare for each operation

\begin{tabular}{|c|c|c|c|c|c|c|}
\hline Field operation & Repetition & Labour $/ \mathrm{h} \cdot \mathrm{hm}^{-2}$ & Fuel/L $\cdot \mathrm{hm}^{-2}$ & Water $/ \mathrm{m}^{3} \cdot \mathrm{hm}^{-2}$ & Electricity $/ \mathrm{kWh} \cdot \mathrm{hm}^{-2}$ & Chemicals $/ \mathrm{kg} \cdot \mathrm{hm}^{-2}$ \\
\hline Cultivation & 4 & 4.39 & 32.89 & - & - & - \\
\hline Weed control & 3 & 24 & - & - & - & $3.6 * *$ \\
\hline Insect/disease control & \multirow{3}{*}{$\begin{array}{c}12 \\
(22)^{*}\end{array}$} & & & & & $4.1 / 18.2 * *(4.6 / 31.4)$ \\
\hline $381 \mathrm{~L} \cdot \mathrm{hm}^{-2}$ & & $16.7(30.6)$ & $52.0(95.3)$ & $4.8(8.8)$ & $1.3(2.4)$ & \\
\hline $759 \mathrm{~L} \cdot \mathrm{hm}^{-2}$ & & $25.0(45.8)$ & 74.9 (137.2) & $9.6(17.6)$ & $2.6(4.8)$ & \\
\hline Harvesting & 3 & 392 & - & - & - & - \\
\hline Transport with trailer & 1 & 24 & 4.2 & - & - & - \\
\hline Pruning & 1 & 120 & - & - & - & - \\
\hline Mulching pruning & 1 & 1.10 & 7.1 & - & - & - \\
\hline Fertilizer application & 1 & 0.73 & 3.5 & - & - & 400 \\
\hline
\end{tabular}

Note: * Values given in brackets refer to 22 treatments; ** Data refers to the mass of active ingredients, Table S1

Besides the direct energy input for production, use and disposal of a product, the CED method also determines the primary energy (both renewable and non-renewable) needed for the production of facilities, raw materials, auxiliary materials and consumables associated with the life cycle of the product investigated $^{[11]}$. The CED of various inputs was determined by process chain analysis according to the ISO 14040:2006 following the principles of the attributional LCA. The CED analysis is based on the results of life cycle inventory (LCI) analysis which includes information on the type and quantity of natural resources used in unit processes associated with the life cycle of a product. These data are available from the Ecoinvent v. 2.2 LCI database $\mathrm{e}^{[25]}$ which is considered to be the most comprehensive LCI database in Europe. This database is integrated into the SimaPro $8 \mathrm{LCA}$ software which was used for the calculations.

For fuels and material inputs that are already included in the Ecoinvent database (fertilizers, diesel fuel, lubricants, electricity, water for plant protection) the calculation of energy equivalent is straightforward. However, some inputs are not available in the database (pesticides, wooden boxes) or need certain adoption (agricultural machines and equipment) before used in the SimaPro software.

The Ecoinvent LCI database provides information on primary energy associated with the production, maintenance and disposal of $1 \mathrm{~kg}$ agricultural machinery. The amount of machinery (in $\mathrm{kg} / \mathrm{hm}^{2}$ ) needed for a specific process in apple production was calculated using Equation (3) ${ }^{[26]}$. Information on typical weight and life time of selected agricultural machinery are available from literature shown in Table $4^{[26]}$, whereas the operation time $\left(\mathrm{h} / \mathrm{hm}^{2}\right)$ of the machinery involved in apple production was calculated from data in Table 3 .

$$
\text { Amount of machinery }(A M)=\frac{\text { Weight } \cdot \text { Operation time }}{\text { Life time }}
$$

Data on primary energy consumption in the life cycle of some pesticides used in apple production are not available in the Ecoinvent LCI database; therefore, they were estimated using literature data. Table S2 summarizes the results of the literature review regarding the $\mathrm{CED}$ of different types of pesticides. Although there are several research papers published in the subject (Table S2) almost all of the references to the CED of pesticides can be traced back to the original data of [27]. Only a few active ingredients of pesticides used in Serbian apple production are covered with previous research. For those active ingredients which are not listed in [27] or other relevant sources the respective CED values were approximated using one of the following procedures: a) if the CED value for the specific active ingredient is missing, but it is available for the substance group the active ingredient belongs, then the average energy requirement of the substance group was attributed to the missing active ingredient; $b$ ) if data on CED of the active ingredient or its respective substance group are both missing, then the average energy requirement of the pesticide type (e.g. herbicides or insecticides) was assigned to the missing active ingredient. The single energy equivalent figure (488 MJ/kg active ingredient (a.i.) for herbicides; $161.5 \mathrm{MJ} / \mathrm{kg}$ a.i for fungicides; $273.5 \mathrm{MJ} / \mathrm{kg}$ a.i for insecticides), which describes the average CED of different types of pesticides, is calculated as the weighted average of pesticides used in apple production in Serbia.

Table 4 Typical weight and life time of agricultural machinery ${ }^{[26]}$ and their respective operation time

\begin{tabular}{|c|c|c|c|c|c|c|}
\hline \multirow{2}{*}{ Machine } & \multirow{2}{*}{$\begin{array}{c}\text { Weight } \\
\text { /kg }\end{array}$} & \multirow{2}{*}{$\begin{array}{c}\text { Life } \\
\text { time } \\
/ \mathrm{h}\end{array}$} & \multicolumn{2}{|c|}{ Operation time/h* } & \multicolumn{2}{|c|}{$\mathrm{AM} / \mathrm{kg} \cdot \mathrm{hm}^{-2}$} \\
\hline & & & 12 treat. & 22 treat. & 12 treat. & 22 treat. \\
\hline Tractor $(47 \mathrm{~kW})$ & 3300 & 7200 & $46.9-63.6$ & $60.8-91.3$ & $21.5-29.1$ & $27.9-41.9$ \\
\hline Field cultivator & 550 & 720 & 4.39 & 4.39 & 3.4 & 3.4 \\
\hline $\begin{array}{l}\text { Fertilizer } \\
\text { broadcaster }\end{array}$ & 200 & 1500 & 0.73 & 0.73 & 0.1 & 0.1 \\
\hline Sprayer & 200 & 700 & $16.7-33.3$ & $30.6-61.1$ & $4.8-9.5$ & $8.7-17.5$ \\
\hline Trailer $(8 \mathrm{t})$ & 1500 & 1200 & 24.00 & 24.00 & 30.0 & 30.0 \\
\hline Rotary harrow & 900 & 540 & 1.10 & 1.10 & 1.8 & 1.8 \\
\hline
\end{tabular}

Note: * Data on operation time are available from Table 3.

Life cycle inventory data of wooden boxes used for transportation of apples is not included in the Ecoinvent database. Therefore, the appropriate CED value was taken from a European study of different packaging systems ${ }^{[28]}$. According to the study, the life cycle primary energy demand of a standard non-reusable wooden box (weight $0.9 \mathrm{~kg}$; dimensions $600 \mathrm{~mm} \times 400 \mathrm{~mm} \times$ $240 \mathrm{~mm}$; load weight $15 \mathrm{~kg}$ ) is $29.1 \mathrm{MJ}$. The primary energy demand for wooden boxes is mainly based on solar energy captured via photosynthesis and only 5.7 MJ of CED comes from non-renewable sources. Many argue that solar energy should not be included in the energy balancing of agricultural systems since, unlike the fossil energy reserves solar energy is practically infinite in the total amount ${ }^{[29]}$. If no stock is depleted, then no opportunity cost is incurred ${ }^{[30]}$. Given these considerations, solar energy embodied in biomass is excluded from energy balancing in this paper. In the reference study ${ }^{[28]}$ it was assumed that after the use phase $100 \%$ of wooden boxes are incinerated and that the energy recovered is used to substitute the average electricity in EU which is generated mainly from non-renewable 
energy sources. This explains the negative CED value of wooden boxes in Table 5. Assuming that there is no end of life
(EoL) energy recovery the non-renewable CED of the wooden box would be $6.3 \mathrm{MJ} / \mathrm{kg}^{[28]}$.

Table 5 Energy equivalents of various inputs used in apple production in Serbia

\begin{tabular}{|c|c|c|c|c|c|c|}
\hline \multirow{2}{*}{ Inputs } & \multirow{2}{*}{ Unit } & \multicolumn{5}{|c|}{ Energy equivalent/MJ unit $^{-1}$} \\
\hline & & Total & Non-renewable & Renewable & Direct & Indirect \\
\hline \multicolumn{7}{|l|}{ Pesticides } \\
\hline Insecticides & $\mathrm{kg}$ a.i. & 273.5 & 266.9 & 6.6 & 0.0 & 273.5 \\
\hline Fungicides & $\mathrm{kg}$ a.i. & 161.6 & 157.7 & 3.9 & 0.0 & 161.6 \\
\hline \multicolumn{7}{|l|}{ Fertilizers } \\
\hline Phosphate $\left(\mathrm{P}_{2} \mathrm{O}_{5}\right)$ & $\mathrm{kg} \mathrm{P}_{2} \mathrm{O}_{5}$ & 24.6 & 23.6 & 1.0 & 0.0 & 24.6 \\
\hline Potassium $\left(\mathrm{K}_{2} \mathrm{O}\right)$ & $\mathrm{kg} \mathrm{K} 2 \mathrm{O}$ & 9.6 & 9.4 & 0.3 & 0.0 & 9.6 \\
\hline \multicolumn{7}{|l|}{ Agricultural machines and equipment } \\
\hline Tractor & $\mathrm{kg}$ & 133.3 & 126.2 & 7.2 & 0.0 & 133.3 \\
\hline General & $\mathrm{kg}$ & 75.3 & 71.2 & 4.1 & 0.0 & 75.3 \\
\hline Tillage & $\mathrm{kg}$ & 85.1 & 80.3 & 4.8 & 0.0 & 85.1 \\
\hline Diesel fuel & $\mathrm{L}$ & 46.4 & 46.3 & 0.1 & 38.9 & 7.5 \\
\hline Lubricant & $\mathrm{L}$ & 46.4 & 46.3 & 0.1 & 0.0 & 46.4 \\
\hline Wooden boxes (with EoL energy recovery) & $\mathrm{kg}$ & -11.5 & -6.0 & -5.5 & 0.0 & -11.5 \\
\hline Wooden boxes (no energy recovery) & $\mathrm{kg}$ & 6.3 & 6.3 & 0 & 0.0 & 6.3 \\
\hline Water for plant protection & $\mathrm{m}^{3}$ & 0.9 & 0.9 & 0.0 & 0.0 & 0.9 \\
\hline Electricity & $\mathrm{kWh}$ & 12.1 & 10.9 & 1.2 & 3.6 & 8.5 \\
\hline \multicolumn{7}{|l|}{ Output } \\
\hline Apple* & $\mathrm{kg}$ & 2.4 & & & & \\
\hline
\end{tabular}

Note: * The energy output is calculated based on the calorific value of the harvested apple $\left(2.4 \mathrm{MJ} / \mathrm{kg}^{[4]}\right)$.

Table 5 summarizes the energy equivalents of various material inputs used in apple production with references to the Ecoinvent process or literature used to estimate its value. Agricultural energy demand can be divided into direct and indirect energy needs ${ }^{[10]}$. Direct energy is the energy consumed on the farm in the form of diesel fuel and electricity to power the engines. Indirect energy is the energy consumed beyond the farm for the provision of the production means (Table 5). Furthermore, total energy demand can be divided into non-renewable and renewable based on the form of primary energy source. For most of the inputs the share of non-renewables and renewables, their total energy equivalent was calculated using the CED method ${ }^{[11]}$ and the appropriate Ecoinvent LCI dataset. The literature used to estimate the CED of various pesticides did not make distinctions between the origins of energy consumed in the life cycle of pesticides; therefore, it was assumed that $97.6 \%$ of the energy demand is fulfilled from non-renewable energy sources. The former value corresponds with the average share of non-renewable energy sources in the life cycle energy requirements of all the pesticides included in the Ecoinvent v. 2.2 LCI database.

Human labor is not usually considered in the energy balance of the agricultural production system ${ }^{[10]}$ since this input is hard to convert to energy figures. Energy costs of human labor might include only the energy for the maintenance of the body, or the energy required to produce food consumed during working hours, or might consider the total energy sequestered in products and services which are used by the agricultural producer and its family ${ }^{[12]}$. The default scenario (S0) does not consider human labor as input in the energy balance. However to demonstrate the extent to which the chosen approach may influence the results of energy analyses three different methods were used to quantify the energy equivalent of agricultural labor. In the first scenario (S1) $2.5 \mathrm{MJ}$ was assumed as the energy equivalent of $1 \mathrm{~h}$ of human labor. A similar value is commonly used in the energy balancing of apple production systems ${ }^{[4,5,9]}$ and refers to the nutritional requirements of workers ${ }^{[13]}$. Scenario 2 takes into account not only the energy content of food consumed by the worker but also the energy required for its provision. As a representative value for this scenario, a $20 \mathrm{MJ} / \mathrm{h}$ was chosen which is within the range suggested by [14]. In this study, $82 \mathrm{MJ} / \mathrm{h}$ was assumed as the highest value (S3) estimated based on the average energy input per working member of society in Serbia using the method recommended by [13].

\subsection{Estimation of energy efficiency parameters}

Energy efficiency parameters are calculated in order to determine the dependencies between the amount of energy consumption and total energy output and production per hectare. Energy efficiency parameters were determined based on the commonly used equations ${ }^{[5,9,15-20]}$. Energy use efficiency (energy input-output ratio), specific energy, energy productivity and net energy were calculated by using total energy inputs and outputs for a unit of surface area $\left(\mathrm{MJ} / \mathrm{hm}^{2}\right)$ and apple yield $\left(\mathrm{kg} / \mathrm{hm}^{2}\right)$ in the following equations:

Energy use efficiency $($ energy ratio $)=\frac{\text { Energy output }\left(\mathrm{MJ} / \mathrm{hm}^{2}\right)}{\text { Energy input }\left(\mathrm{MJ} / \mathrm{hm}^{2}\right)}$

$$
\begin{gathered}
\text { Energy productivity }=\frac{\text { Apple output }\left(\mathrm{kg} / \mathrm{hm}^{2}\right)}{\text { Energy input }\left(\mathrm{MJ} / \mathrm{hm}^{2}\right)}(\mathrm{kg} / \mathrm{MJ}) \\
\text { Specific energy }=\frac{\text { Energy input }\left(\mathrm{MJ} / \mathrm{hm}^{2}\right)}{\text { Apple output }\left(\mathrm{kg} / \mathrm{hm}^{2}\right)}(\mathrm{MJ} / \mathrm{kg})
\end{gathered}
$$

Net energy $=$

Energy output $\left(\mathrm{MJ} / \mathrm{hm}^{2}\right)-$ Energy input $\left(\mathrm{MJ} / \mathrm{hm}^{2}\right)\left(\mathrm{MJ} / \mathrm{hm}^{2}\right)$

\section{Results and discussion}

Table 6 and Figure 2 show the type of inputs associated with apple production and their corresponding life cycle energy equivalents. 
Table 6 Cumulative energy demand for apple production (for 22 treatments and application rate of $1150 \mathrm{~L} / \mathrm{hm}^{2}$ )

\begin{tabular}{|c|c|c|c|c|c|}
\hline Flows & Unit & $\begin{array}{l}\text { Quantity per } \\
\text { unit area/hm }{ }^{2}\end{array}$ & $\begin{array}{c}\text { Total energy } \\
\text { Equivalent } / \mathrm{MJ} \cdot \mathrm{hm}^{-2}\end{array}$ & $\begin{array}{l}\text { Total non-renewable energy } \\
\text { equivalent } / \mathrm{MJ}_{\mathrm{nr}} \cdot \mathrm{hm}^{-2}\end{array}$ & $\begin{array}{l}\text { Share in } \\
\text { total energy/\% }\end{array}$ \\
\hline Human labour & $\mathrm{h}$ & 627.7 & 0 & 0 & $0.0(0.0)$ \\
\hline Pesticides & & 0.0 & 8097 & 7903 & $16.8(-100.6)$ \\
\hline Herbicides & $\mathrm{kg}$ a.i. & 3.6 & 1757 & 1715 & $3.7(28.4)$ \\
\hline Insecticides & kg a.i. & 4.6 & 1269 & 1239 & $2.6(20.5)$ \\
\hline Fungicides & $\mathrm{kg}$ a.i. & 31.4 & 5071 & 4949 & $10.5(81.9)$ \\
\hline Fertilizers & & 0.0 & 4535 & 4410 & $9.4(73.3)$ \\
\hline Nitrogen (as N) & $\mathrm{kg}$ & 32.0 & 2036 & 1997 & $4.2(32.9)$ \\
\hline Phosphate $\left(\right.$ as $\left.\mathrm{P}_{2} \mathrm{O}_{5}\right)$ & $\mathrm{kg}$ & 64.0 & 1574 & 1513 & $3.3(25.4)$ \\
\hline Potassium (as $\left.\mathrm{K}_{2} \mathrm{O}\right)$ & $\mathrm{kg}$ & 96.0 & 925 & 900 & $1.9(14.9)$ \\
\hline Machinery & & 0.0 & 9897 & 9258 & $20.6(159.9)$ \\
\hline Tractor & $\mathrm{kg}$ & 41.9 & 5581 & 5282 & $11.6(90.2)$ \\
\hline Field cultivator & $\mathrm{kg}$ & 3.4 & 285 & 269 & $0.6(4.6)$ \\
\hline Fertilizer broadcaster & $\mathrm{kg}$ & 0.1 & 7 & 7 & $0.0(0.1)$ \\
\hline Sprayer & $\mathrm{kg}$ & 17.5 & 1314 & 1243 & $2.7(21.2)$ \\
\hline Trailer & $\mathrm{kg}$ & 30.0 & 2553 & 2311 & $5.3(41.2)$ \\
\hline Rotary harrow & $\mathrm{kg}$ & 1.8 & 156 & 147 & $0.3(2.5)$ \\
\hline Diesel fuel & $\mathrm{L}$ & 226.8 & 10521 & 10497 & $21.9(170.0)$ \\
\hline Lubricant & $\mathrm{L}$ & 2.3 & 105 & 105 & $0.2(1.7)$ \\
\hline Wooden boxes & $\mathrm{kg}$ & 2354.4 & $-27076(14833)$ & $-14126(14833)$ & $30.8(-437.4)$ \\
\hline Water for plant protection & $\mathrm{m}^{3}$ & 26.4 & 24 & 24 & $0.0(0.4)$ \\
\hline Electricity & kWh & 7.2 & 87 & 78 & $0.2(1.4)$ \\
\hline Total inputs & & & $6190(48099)$ & $18149(47108)$ & $100(100)$ \\
\hline Apple & $\mathrm{kg}$ & 39240 & 94176 & 94176 & 100 \\
\hline Pruning wood & $\mathrm{kg}$ & 3080 & 0 & 0 & 0.0 \\
\hline Total outputs & & & 94176 & 94176 & 100 \\
\hline
\end{tabular}

Note: * Data in brackets refer to the scenario when no energy recovery is assumed after the use phase of the wooden boxes, e.g. wooden boxes are landfilled.

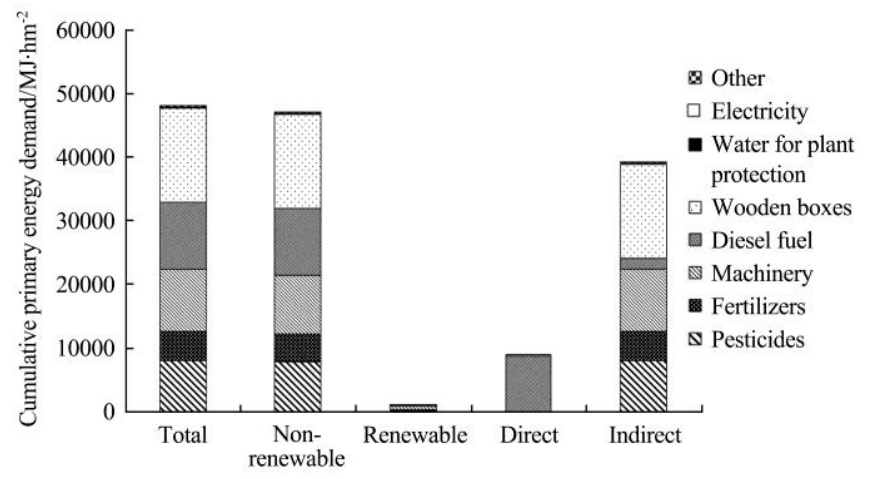

Note: Assuming no energy recovery at EoL of wooden boxes.

Figure 2 Primary energy demand for apple production differentiated according to energy type (for 22 treatments and application rate of $1150 \mathrm{~L} / \mathrm{hm}^{2}$ )

Detailed results are provided only for the scenario which involves 22 annual treatments with an application rate of $1150 \mathrm{~L} / \mathrm{hm}^{2}$ which is usually the case with chemical protection of apple fruit that is applied in Vojvodina and other regions in central Europe with similar climatic conditions ${ }^{[8]}$. Aggregated results of other scenarios assuming different numbers of treatments and application rates are provided in Figures 3 and 4.

Assuming no energy recovery at the EoL of wooden boxes and 22 treatments per year with an application rate of $1150 \mathrm{~L} / \mathrm{hm}^{2}$ the primary energy demand of apple production was estimated at $48 \mathrm{GJ} / \mathrm{hm}^{2}$ which is significantly less than the calorific value of the apple output ( $94 \mathrm{GJ} / \mathrm{hm}^{2}$; Table 6). Almost one-third of the total primary energy inputs are associated with the use of wooden boxes. Disposable wooden boxes weighed $2354 \mathrm{~kg} / \mathrm{hm}^{2}$, and their production required $15 \mathrm{GJ} / \mathrm{hm}^{2}$. Energy inputs associated with agricultural mechanization have a significant share $(\sim 30 \%)$ in total CED due to significant energy required for the provision of diesel fuel and the production and maintenance of agricultural machinery. Research results indicate that pesticides and fertilizers are also important contributors to the CED of apple production making around $17 \%$ and $9 \%$ of the total CED, respectively.

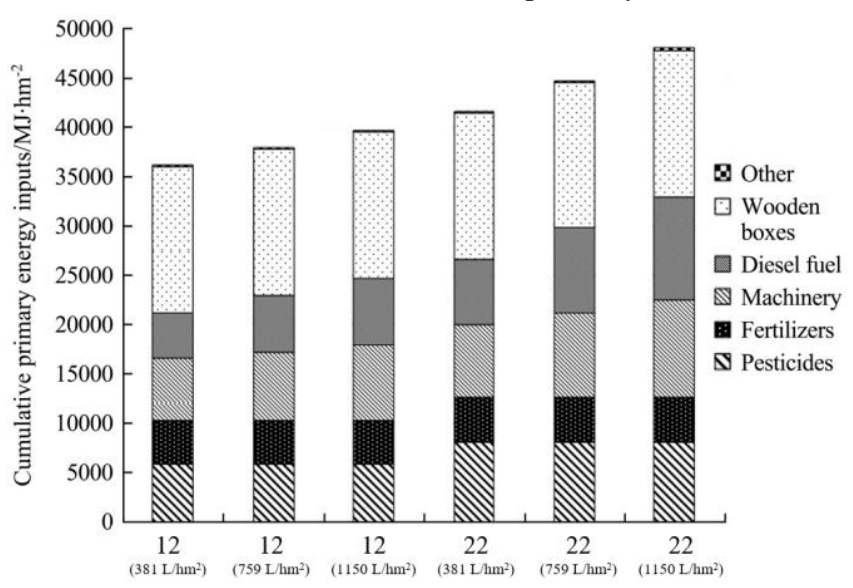

Note: Assuming no energy recovery at EoL of wooden boxes.

Figure 3 Changes of individual energy inputs with respect to the application rate and number of treatments

Figure 3 shows the variation of CED (without considering human labor and solar energy captured via photosynthesis as energy inputs) with respect to different application rates $(381,759$ and $1150 \mathrm{~L} / \mathrm{hm}^{2}$ ) and the number of treatments (12 and 22). The total CED value ranged from $36.1 \mathrm{GJ} / \mathrm{hm}^{2}$ to $48.1 \mathrm{GJ} / \mathrm{hm}^{2}$ depending on the norms and the number of treatments. Reduced number of treatments and application rates reduced energy inputs associated with diesel fuel, machinery, chemicals, water and electricity, while the rest of the energy inputs remained unchanged (Figure 3). By reducing the number of treatments from 22 to 12 , and application rate from $1150 \mathrm{~L} / \mathrm{hm}^{2}$ to $381 \mathrm{~L} / \mathrm{hm}^{2}$, the use of 
machinery reduced from $91.3 \mathrm{~h} / \mathrm{hm}^{2}$ to $46.9 \mathrm{~h} / \mathrm{hm}^{2}$, which provides a saving of $3.7 \mathrm{GJ} / \mathrm{hm}^{2}$. Simultaneously, $127.14 \mathrm{~L} / \mathrm{hm}^{2}$ of diesel fuel (or $5.9 \mathrm{GJ} / \mathrm{hm}^{2}$ ) was saved. A smaller number of treatments reduced the quantities of used insecticides and fungicides by $2.6 \mathrm{~kg} / \mathrm{hm}^{2}$ and $27.7 \mathrm{~kg} / \mathrm{hm}^{2}$, respectively, which resulted in a saving of $2.6 \mathrm{GJ} / \mathrm{hm}^{2}$.

Figure 4 shows the human labor requirement of apple production $\left(\mathrm{h} / \mathrm{hm}^{2}\right.$ and $\mathrm{MJ} / \mathrm{hm}^{2}$ ) and the contribution of human labor to the total energy demand assuming different energy equivalent of a unit of human labor. Considerable saving in human labor hours (ca. $44 \mathrm{~h} / \mathrm{hm}^{2}$ ) can be achieved by reducing the number of treatments from 22 to 12, and application rate from $1150 \mathrm{~L} / \mathrm{hm}^{2}$ to $381 \mathrm{~L} / \mathrm{hm}^{2}$. Depending on the applied method for the determination of the energy equivalent of human labor, as well as the norms and number of treatments, the total energy input ranged from $37.57 \mathrm{GJ} / \mathrm{hm}^{2}$ to $94.46 \mathrm{GJ} / \mathrm{hm}^{2}$.

Table 7 shows that the reduced number of treatment and application rates considerably improves the energy efficiency of apple production. Also, reduced the number of treatment decrease dangerous from an environmental and healthy point of view. By reducing the number of treatments and application rates the energy use efficiency, energy productivity, specific energy and net energy could be reduced by $24.9 \%, 24.8 \%,-33.7 \%$ and $20.6 \%$, respectively. It should be noted that the energy balance did not include human labor and solar energy captured in biomass.

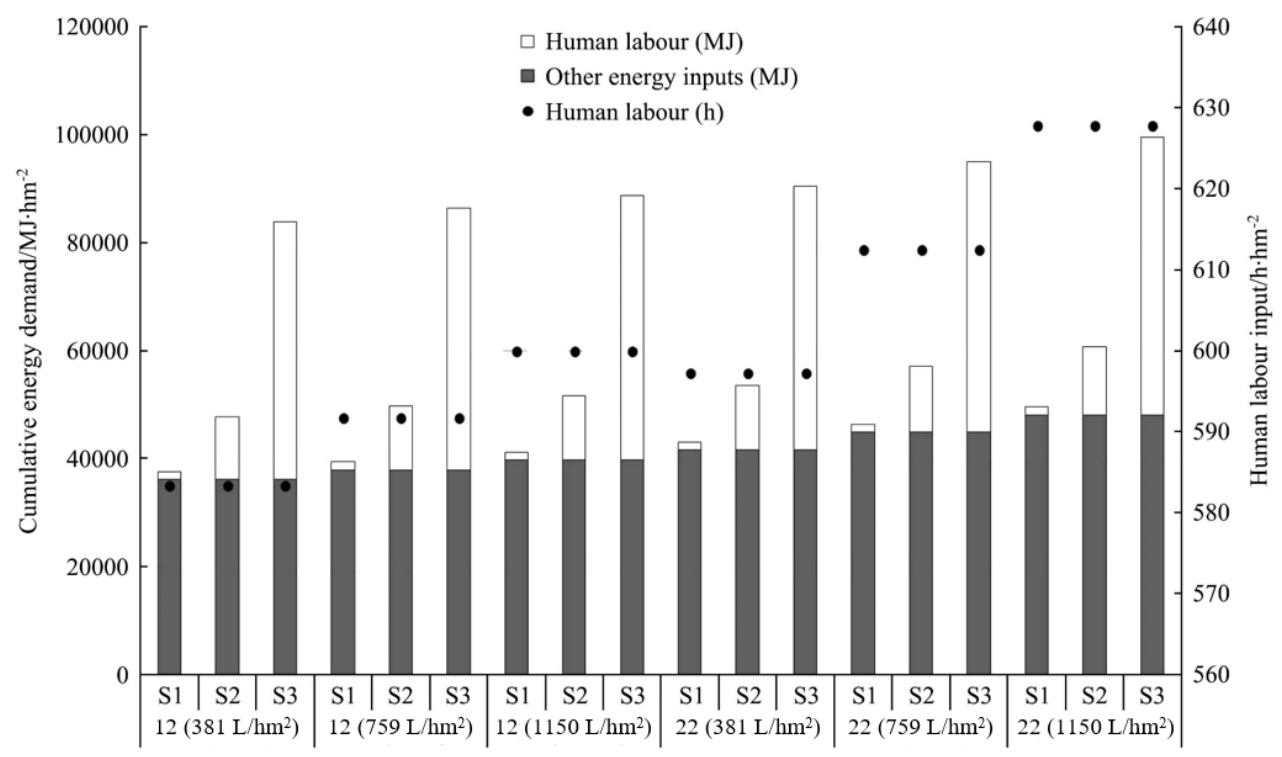

Note: Assuming no energy recovery at EoL of wooden boxes.

Figure 4 Inputs of human labor with respect to the application rate and number of treatments with pesticides

Table 7 Calculated energy efficiency parameters of apple production

\begin{tabular}{|c|c|c|c|c|c|c|}
\hline \multirow[b]{3}{*}{ Application rate $/ \mathrm{L} \cdot \mathrm{hm}^{-2}$} & \multicolumn{6}{|c|}{ Number of treatments } \\
\hline & \multicolumn{3}{|c|}{12} & \multicolumn{3}{|c|}{22} \\
\hline & 381 & 759 & 1150 & 381 & 759 & 1150 \\
\hline Energy use efficiency & 2.61 & 2.49 & 2.37 & 2.27 & 2.10 & 1.96 \\
\hline Energy productivity $/ \mathrm{kg} \cdot \mathrm{MJ}^{-1}$ & 1.09 & 1.04 & 0.99 & 0.94 & 0.88 & 0.82 \\
\hline Specific energy $/ \mathrm{MJ} \cdot \mathrm{kg}^{-1}$ & 0.92 & 0.97 & 1.01 & 1.06 & 1.14 & 1.23 \\
\hline Net energy/GJ & 58.06 & 56.28 & 54.50 & 52.60 & 49.34 & 46.08 \\
\hline
\end{tabular}

Note: * Assuming no energy recovery at EoL of wooden boxes.

The obtained energy efficiency parameters in this study are relatively favorable if compared to the results of similar studies in other countries. In the reviewed studies ${ }^{[4-6,9,6,21,22]}$, the specific energy of apple production ranged between $1.59 \mathrm{MJ} / \mathrm{kg}$ (Turkey) and $2.8 \mathrm{MJ} / \mathrm{kg}$ (Germany). Differences in region-specific energy requirements and yields can largely explain the variations in the obtained energy efficiency parameters; however, it is important to note that the results of various studies are not always comparable due to different system boundaries and methodological approaches applied. These differences are mainly observable in the methods used to calculate the output side of the energy balance and the approaches used to account for the energy associated with human labor input and wooden boxes.

In this study, on the output side, only the energy content of the harvested apple was considered. The energy content of pruning wood was not accounted for on the output side since pruning wood is usually chopped and spread over the orchard in Vojvodina. In some similar studies, researchers assign energy value for pruning $\operatorname{wood}^{[4,5]}$ which can significantly improve the energy ratio of apple production. This approach is acceptable only in cases when pruning wood is used for energetic purposes. In that case, however, the nutrients removed with pruning wood should be balanced with additional amounts of manure and/or mineral fertilizers which increase the input side of the energy balance. Based on [4] it can be estimated that the removal of $1000 \mathrm{~kg}$ of pruning wood would lead to the removal of $5.53 \mathrm{~kg} \mathrm{~N}, 1.24 \mathrm{~kg}$ $\mathrm{P}_{2} \mathrm{O}_{5}$ and $2.75 \mathrm{~kg} \mathrm{P}_{2} \mathrm{O}_{5}$ from the soil. Consequently, each ton of pruning wood removed would increase the input side of energy balance by $408 \mathrm{MJ}$ due to the additional use of fertilizers.

Research results indicate that the choice of whether to include human labor on the input side of the energy balance can significantly affect the results. In several previous studies, the energy cost of human labor was included in the energy balancing of apple production ${ }^{[4,5,9]}$. However, it is important to note that the inclusion of human labor is rather controversial. Fossil energy and human labor are too different to be expressed in the same unit; consequently, there are hardly comparable ${ }^{[29]}$. Furthermore, there are at least nine different methods to estimate the energy equivalent of human labor ${ }^{[12]}$ with estimates ranging from $0.2 \mathrm{MJ} / \mathrm{h}$ to $20 \mathrm{GJ} / \mathrm{h}^{[14]}$. As indicated in Figure 4, the results of energy balancing are very sensitive to the chosen method used to determine the energy equivalent of human labor. The share of 
human labor in total energy inputs of apple production can be less than $4 \%$, if calculated based on the physical needs of humans, or higher than $50 \%$, if the social energy consumption is considered as the basis for its determination.

Another important source of confusion is the assumed end-of-life scenario for wooden boxes. The estimated energy demands of apple production vary in a significant range depending on the assumed end of life scenario for wooden boxes (e.g. landfilling vs. incineration with energy recovery). Since the solar energy bounded in biomass via photosynthesis was not considered as energy input in the study, and due to the negligible consumption of other renewable energy sources in the life cycle of inputs (Table 5 ), the primary non-renewable energy demand is similar to total primary energy demand. If energy recovery from wooden boxes is an option; for example, the used wooden boxed incinerated in municipal solid waste incineration plant with energy recovery, then the total CED of apple production can be significantly reduced (from 48 to $6.2 \mathrm{GJ} / \mathrm{hm}^{2}$ assuming that $100 \%$ of wooden boxes are incinerated; Table 6).

\section{Conclusions}

Regardless of the high uncertainties the presented analysis clearly shows that a smaller number of treatments and reduced application rates reduce energy consumption in apple production. Furthermore, it minimizes the risk of contamination of soil and the environment. Bad pesticide application causes over $25 \%$ and even $35 \%$ of pesticide to fall on the ground. Losses due to ground drift analyzed in Idared apple orchard which was 7 years old and concluded that losses were $325.3 \mathrm{~L} / \mathrm{hm}^{2}$ with $1289 \mathrm{~L} / \mathrm{hm}^{2}$ application rate and operating pressure of $15 \mathrm{bar}^{[3]}$. Reduced application rate to $801 \mathrm{~L} / \mathrm{hm}^{2}$ and operating pressure of 8 bar caused ground drift to decrease to $50.3 \mathrm{~L} / \mathrm{hm}^{2}$. Normally, the given results are not a general rule but a result of good calibration and careful consideration of weather conditions in which the treatment was carried out. Together with the timely identification of pathogens and a good choice of agents, all three factors influencing the efficiency and acceptability of chemical agents from ecological aspects are met. This also provides conditions for a smaller number of treatments with low application rates, as well as some energy saving. It should be particularly noted that the efficiency of low rates and a small number of treatments depends on the adjustment of nozzles and all work parameters (traveling speed, air velocity, operating pressure, selection of nozzles) to weather conditions in the orchard.

The results of this research would not be sufficient if the biological efficiency of low and medium application rates, as well as the reduced number of treatments, was not proved. This is why the analysis of the biological efficiency of low and medium application rates was performed during 2009 and 2010. A twoyear bio-efficiency trial on Venturia inaequalis and Podosphaera leucitricha in apple confirmed that during suitable weather conditions, and with properly adjusted sprayer settings, a reduced application rate of $381 \mathrm{~L} / \mathrm{hm}^{2}$ gave the same quality of crop protection as a medium application rate of $759 \mathrm{~L} / \mathrm{hm}^{2[3,32]}$. Similar findings were reported by $[1,31]$ who argue that under typical conditions in Vojvodina 12 treatments are sufficient if weather conditions and pest and disease development are constantly and carefully monitored. In order to accomplish that, the education of agricultural producers is necessary to allay the fear and eliminate prejudice about a smaller number of treatments which may cause inadequate chemical protection. Correct application of pesticides with properly adjusted nozzles to the requirements of the orchard can ensure efficient protection with minimal losses caused by air drift.

\section{Acknowledgements}

This paper was supported by Ministry of Education, Science and Technology Development of Republic of Serbia (No. 451-03-68/2020-14/ 200117)

\section{[References]}

[1] Statistical Office of the Republic of Serbia. Statistical Yearbook of Serbia year 2010. 2019; COBISS.SR-ID 19184399. ISSN 0354-4206.

[2] Republican statistical office. CENSUS 2012 in Republic of Serbia. Republican Statistical Office, 2012.

[3] Sedlar A, Bugarin R, Nuyttens D, Turan J, Zoranović M, Ponjičan O, et al. Quality and efficiency of apple orchard protection affected by sprayer type and application rate, Spanish Journal of Agricultural Research, 2013; 11(4): 935-944.

[4] Strapatsa V A, Nanos D G, Tsatsarelis A C. Energy flow for integrated apple production in Greece. Agriculture Ecosystems \& Environment, 2006; 116: 176-180.

[5] Sinasi A, Handan A, Hatice K. An analysis of energy use and input costs for apple production in Turkey. Journal of Food, Agriculture and Environment, 2012; 10(2): 473-479.

[6] Mousavi-Avval S H, Rafiee S, Mohammadi A. Optimisation of energy consumption and input cost for apple production in Iran using data envelopment analysis. Energy, 2011; 36: 909-916.

[7] Ponjican O, Bajkin A, Dimitrijevic A, Savin L, Tomic M, Simikic M, et al. The effects of working parameters and tillage quality on rotary tiller specific work requirement. African Journal of Agricultural Research, 2011; 6(31): 6513-6524.

[8] Bugarin R, Sedlar A. Possibilities for reducing losses due to drift in mechanized protection of apples. Contemporary Agricultural Engineering, 2011; 37(4): 377-386.

[9] Rafiee S, Mousavi-Avval S H, Mohammadi A. Modeling and sensitivity analysis of energy inputs for apple production in Iran. Energy, 2010; 35(8): 3301-3306.

[10] Diepenbrock W. Energy balance in crop production. Journal of Agricultural Science and Technology B, 2012; 2(5B): 527-533.

[11] Frischknecht R, Jungbluth N, Althaus H J, Bauer C, Doka G, Dones R, et al. Implementation of life cycle impact assessment methods. Ecoinvent Report, 2007; No.3, v2.0. Swiss Centre for Life Cycle Inventories, Dübendorf, 2007; 139p.

[12] Fluck R C. Energy of human labour. Energy in Farm production, 1992; 6: $31-37$.

[13] Giampietro M, Pimentel D. Assessment of the energetics of human labour Agriculture, Ecosystems \& Environment, 1990; 32(3-4): 257-272.

[14] Giampietro M, Allen T F, Mayumi K. The epistemological predicament associated with purposive quantitative analysis. Ecological Complexity, 2006; 3(4): 307-327.

[15] Tabatabaeefar A, Emamzadeh H, Varnamkhasti M G, Rahimizadeh R, Karimi M. Comparison of energy of tillage systems in wheat production. Energy, 2009; 34: 41-45.

[16] Mani I, Kumar P, Panwar J S, Kant K. Variation in energy consumption in production of wheat-maize with varying altitudes in hilly regions of Himachal Pradesh, India. Energy, 2007; 32: 2336-2339.

[17] Rathke G W, Wienhold B J, Wilhelm W W, Diepenbrock W. Tillage and rotation effect on corn-soybean energy balances in eastern Nebraska. Soil and Tillage Research, 2007; 97: 60-70

[18] Mobtaker H G, Keyhani A, Mohammadi A, Rafiee S, Akram A. Sensitivity analysis of energy inputs for barley production in Hamedan Province of Iran. Agriculture, Ecosystem and Environment, 2010; 137: 367-372.

[19] Barut Z B, Ertekin C, Karaabac H A. Tillage effects on energy use for corn silage in Mediterranean Coastal of Turkey. Energy, 2011; 36: 5466-5475

[20] Laik R, Sharma S, Idris M, Singh A K, Singh S S, Bhatt B P, et al Integration of conservation agriculture with best management practices for improving system performance of the rice-wheat rotation in the Eastern 
Indo-Gangetic Plains of India. Agriculture, Ecosystems and Environment, 2014; 195: 68-82

[21] Blanke M, Burdick B. Food (miles) for thought. Environmental Science and Pollution Research, 2005; 12(3): 125-127.

[22] Reganold J P, Glover J D, Andrews P K, Hinman H R. Sustainability of three apple production systems. Nature, 2001; 410: 926-930.

[23] Röhrlich M, Mistry M, Martens P N, Buntenbach S, Ruhrberg M, Dienhart $\mathrm{M}$, et al. A method to calculate the cumulative energy demand (CED) of lignite extraction. The International Journal of Life Cycle Assessment, 2000; 5(6): 369-373.

[24] Huijbregts M A, Hellweg S, Frischknecht R, Hendriks H W, Hungerbühler K, Hendriks A J. Cumulative energy demand as predictor for the environmental burden of commodity production. Environmental Science \& Technology, 2010; 44(6): 2189-2196.

[25] Frischknecht R, Jungbluth N, Althaus H J, Doka G, Dones R, Heck T, et al. The ecoinvent database: Overview and methodological framework. International Journal of Life Cycle Assessment, 2005; 10: 3-9.

[26] Nemecek T, Kägi T. Life cycle inventories of Swiss and European agricultural production systems. Final report Ecoinvent, 2007; v.2.0, No. 15a, Zurich and Dubendorf, Switzerland, 2007; 308p.

[27] Green M B. Energy in pesticide manufacture, distribution and use. In: Helsel Z R (editor) Energy in Plant Nutrition and Pest Control, Amsterdam: Elsevier, 1987; pp.165-177.

[28] Albrecht S, Brandstetter P, Beck T, Fullana-I-Palmer P, Grönman K, Baitz $\mathrm{M}$, et al. An extended life cycle analysis of packaging systems for fruit and vegetable transport in Europe. The International Journal of Life
Cycle Assessment, 2013; 18(8): 1549-1567.

[29] Refsgaard K, Halberg N, Kristensen E S. Energy utilization in crop and dairy production in organic and conventional livestock production systems. Agricultural Systems, 1998; 57(4): 599-630.

[30] Leach G. Energy and food production. Food Policy, 1976; 1(1): 62-73.

[31] Gvozdenović D. Dense planting of apples, pears and quinces. University book. Prometej, 2007; 320p. (In Serbian)

[32] Sedlar A, Bugarin R, Turan J, Višacki V. Analyze of drift loses in plum and apple orchards and measures for their reducing. Proceeding of $2 \mathrm{nd}$ International Scientific Conference, Soil and Crop Management: Adaptation and Mitigation of Climate Change. Osijek, 2013; pp.309-316.

[33] Audsley E. Harmonisation of environmental life cycle assessment for agriculture. Concerted Action AIR3-CT94-2028. European Commission, DG VI Agriculture, Final Report, 1997; 139p.

[34] Audsley E, Stacey K, Parsons D J, Williams A G. Estimation of the greenhouse gas emissions from agricultural pesticide manufacture and use. Cranfield University, 2009; doi: 10.13140/RG.2.1.5095.3122

[35] Barber A. Seven case study farms: total energy \& carbon indicators for New Zealand arable \& outdoor vegetable production. AgriLINK New Zealand Ltd, February 2004.

[36] Lillywhite R, Chandler D, Grant W, Lewis K, Firth C, Schmutz U, et al Environmental footprint and sustainability of horticulture (including potatoes) - a comparison with other agricultural sectors. Final report of project WQ0101. 2007; Defra, London. http://randd.defra.gov.uk/ Document.aspx?Document=WQ0101_6747_FRP.doc. Accessed on [2016-07-20]

\section{Appendix}

Table S1 Type, active ingredient (a.i.) and application rate of pesticides used in apple production

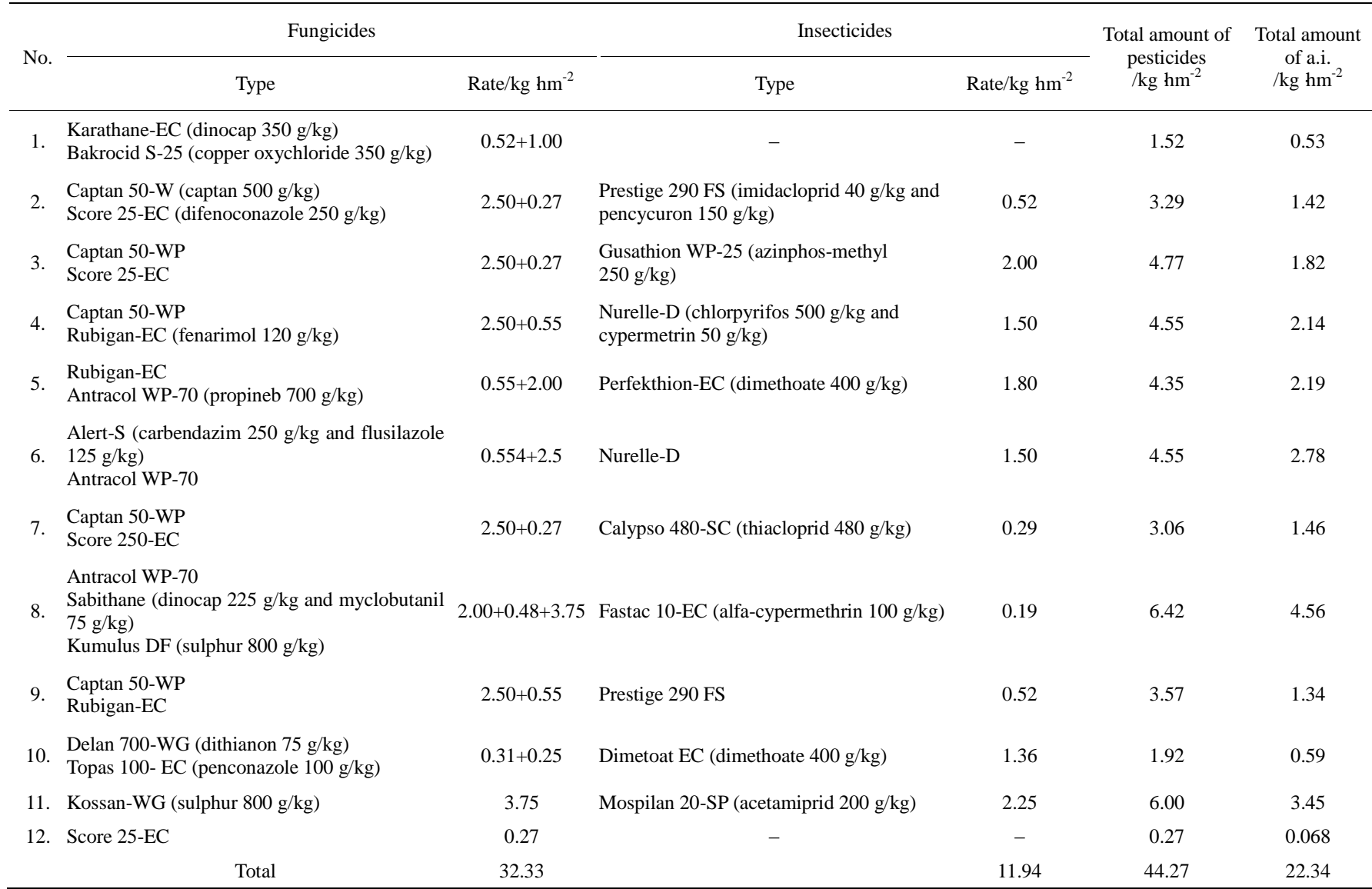

Note: * Data in the table refer to the situation with 12 annual treatments. The scenario with 22 treatments includes five addition treatments with the combination of Captan 50-W, Score 25-EC and Prestige 290 FS pesticides (i.e. as the № 2 treatment) and five addition treatments with the combination of Captan 50-W and Score 25-EC pesticides (i.e. as the No. 2 treatment but without the insecticide). 
Table S2 Primary energy used for production, formulation and packaging of pesticides according to various authors (MJ/kg a.i.)

\begin{tabular}{|c|c|c|c|c|c|c|c|c|}
\hline Active ingredient & Pesticide type & Substance group & {$[27] * * * *$} & {$[33]$} & {$[34]$} & {$[35]$} & {$[36]$} & In this study \\
\hline Dinocap & Fungicide, Acaricide & Dinitrophenol & $193^{*}$ & n.a. & n.a. & $210^{*}$ & $168^{*}$ & 190 \\
\hline Copper oxychloride & Fungicide, Repellent & Inorganic compound & n.a. & n.a. & n.a. & $210 *$ & $168 *$ & 189 \\
\hline Captan & Fungicide, Bactericide & Phthalimide & 135 & n.a. & n.a. & $210 *$ & $168^{*}$ & 135 \\
\hline Difenoconazole & Fungicide & Triazole & $193 *$ & n.a. & n.a. & $210 *$ & $168 *$ & 190 \\
\hline Fenarimol & Fungicide & Pyrimidine & $193^{*}$ & n.a. & n.a. & $210 *$ & $168 *$ & 190 \\
\hline Carbendazim & Fungicide, Metabolite & Benzimidazole & $417 * *$ & 400 & 410 & $210 *$ & $168 *$ & 405 \\
\hline Flusilazole & Fungicide & Triazole & $193^{*}$ & 176 & 529 & $210 *$ & $168^{*}$ & 190 \\
\hline Myclobutanil & Fungicide & Triazole & $193^{*}$ & n.a. & n.a. & $210 *$ & $168^{*}$ & 190 \\
\hline Sulphur & Fungicide & Inorganic compound & n.a. & n.a. & n.a. & $210 *$ & $168^{*}$ & 189 \\
\hline Dithianon & Fungicide & Quinone & $193^{*}$ & n.a. & n.a. & $210 *$ & $168^{*}$ & 190 \\
\hline Penconazole & Fungicide & Triazole & $193^{*}$ & n.a. & n.a. & $210^{*}$ & $168^{*}$ & 190 \\
\hline \multicolumn{8}{|c|}{ Fungicides (weighted average) $* * *$} & 161.6 \\
\hline Imidacloprid & Insecticide, Veterinary substance & Neonicotinoid & $234 *$ & n.a. & n.a. & $310 *$ & $214^{*}$ & 252 \\
\hline Azinphos-methyl & Insecticide, Acaricide & Organophosphate & $234 *$ & n.a. & n.a. & $310 *$ & $214^{*}$ & 252 \\
\hline Chlorpyrifos & Insecticide & Organophosphate & $181 * *$ & n.a. & 324 & $310^{*}$ & $214^{*}$ & 324 \\
\hline Cypermethrin & Insecticide, Veterinary substance & Pyrethroid & 600 & 583 & 600 & $310 *$ & $214^{*}$ & 594 \\
\hline Dimethoate & Insecticide, Acaricide, Metabolite & Organophosphate & $181 * *$ & n.a. & n.a. & $310 *$ & $214^{*}$ & 228 \\
\hline Thiacloprid & Insecticide, Molluscicide & Neonicotinoid & $234 *$ & n.a. & n.a. & $310 *$ & $214^{*}$ & 252 \\
\hline Alpha-cypermethrin & Insecticide, Veterinary substance & Pyrethroid & $234 *$ & n.a. & 518 & $310^{*}$ & $214^{*}$ & 252 \\
\hline Acetamiprid & Insecticide & Neonicotinoid & $234 *$ & n.a. & n.a. & $310 *$ & $214 *$ & 252 \\
\hline \multicolumn{8}{|c|}{ Insecticides (weighted average) $* * *$} & 273.5 \\
\hline Glyphosate, isopropylamine salt & Herbicide & Phosphonoglycine & 474 & n.a. & 474 & 550 & 454 & 488 \\
\hline
\end{tabular}

Notes: $*$ average for fungicides or insecticides; ** average for substance group; *** study-specific value calculated by taking into account the specific types and quantities of pesticides used in apple production; **** The original values from [27] are increased by $20 \mathrm{MJ} / \mathrm{kg}$ a.i. in order to include the energy associated with packaging and transport. 